\title{
MITOCHONDRIAL DNA POLYMORPHISM IN JAPANESE LIVING IN HOKKAIDO
}

\author{
Shinji Harihara, Momoki Hirai, and Keiichi Omoto \\ Department of Anthropology, Faculty of Science, \\ The University of Tokyo, Tokyo 113, Japan
}

\begin{abstract}
Summary Restriction enzyme fragment patterns of human mitochondrial DNA (mtDNA) were analyzed using total DNAs from the blood cells of 122 Japanese (Ainu and Non-Ainu) living in Hokkaido, northern Japan. Polymorphisms were detected and the mtDNAs were classified into eleven types using four enzymes, AvaII, HincII, HpaI and PvuII. The distribution of the mtDNA morphs was not significantly different between the Ainu and the Non-Ainu samples, supporting the views that the Ainu are genetically one of the Mongoloid populations.
\end{abstract}

\section{INTRODUCTION}

Human mtDNA is a 16.5 kilo base $(\mathrm{kb})$ circular molecule which has been completely sequenced and its gene composition analyzed (Anderson et al., 1981; Chomyn et al., 1985). Since the pioneer work by Brown (1980), polymorphism of human mtDNA has attracted a great deal of attention of human population geneticists and anthropologists (Brown, 1980; Denaro et al., 1981; Blanc et al., 1983; Cann and Wilson, 1983; Johnson et al., 1983; Cann et al., 1984; Horai et al., 1984; Wallace et al., 1985; Horai and Matsunaga 1986).

The Ainu of Hokkaido, the northernmost island of Japan, is considered to be derived from the original population of northern Japan. Although earlier anthropological observations based on morphological features gave birth to the belief that the Ainu belonged to the Caucasoid race, recent genetic studies indicated their close relations to the Mongoloid race (Misawa and Hayashida, 1968; Mittal et al., 1972; Omoto, 1972; Omoto, 1975). However, because of the considerable admixture in the present-day Ainu (Omoto, 1973), the findings based on the variation of nuclear genes are subject to the question as to racial origins of the Ainu.

In the present study, polymorphism of mtDNA of the Ainu and the Non-Ainu Japanese living in Hokkaido was analyzed. Since males of immigrant populations

Received April 9, 1986 
are likely to be the predominant source of gene introduction into the aboriginal populations, it was hoped that the information of mtDNA, because of its maternal inheritance (Hutchison et al., 1974; Giles et al., 1980; Case and Wallace, 1981), may give a clue to answer the question, whether the genetic similarity between the Ainu and the Mongoloid populations including the Non-Ainu Japanese is ascribed to gene flow.

\section{MATERIALS AND METHODS}

Samples. Five $\mathrm{ml}$ of blood samples were obtained from 122 adult Japanese (48 Ainu and 74 Non-Ainu) living in Hidaka district, Hokkaido.

DNA extraction. Total human DNA was extracted from the buffy coat by the method of Kan et al. (1977). After an overnight digestion of blood cells with proteinase $\mathrm{K}$ in $50 \mathrm{~mm}$ Tris- $\mathrm{HCl}$ at $\mathrm{pH} 7.5 / 100 \mathrm{~mm} \mathrm{NaCl} / 1 \mathrm{~mm}$ EDTA/0.5\% SDS, DNA was extracted with saturated phenol and then dialyzed against $10 \mathrm{~mm}$ Tris- $\mathrm{HCl}$ at $\mathrm{pH} 8.0 / 5 \mathrm{~mm}$ EDTA. After the dialysis, DNA was precipitated with ethanol, dried and stocked in $20 \mathrm{~mm}$ Tris- $\mathrm{HCl}$ at $\mathrm{pH} 8.0 / 0.1 \mathrm{~mm}$ EDTA.

Restriction enzyme fragment analysis. Two to five $\mu \mathrm{g}$ of total DNA was used for the digestion of each restriction endonuclease. Five restriction enzymes used in the present study ( $A v a \mathrm{II}, B a m \mathrm{HI}$, HincII and $H p a \mathrm{I}$ ) were purchased from Takara Shuzo Co., Ltd., Kyoto, and the digestion buffers were those recommended by the manufacturer. After the overnight digestion at $37^{\circ} \mathrm{C}$, dye markers of bromophenol blue and xylene cyanol and glycerine (to a final concentration $10 \% \mathrm{v} / \mathrm{v}$ ) were added to digested DNA. The digested DNA fragments were separated in $0.7 \%-1.8 \%$ agarose gel. The buffer for electrophoresis used was E-buffer ( $40 \mathrm{mM}$ Tris-acetate at $\mathrm{pH}$ 7.9/20 mм sodium acetate/1 mм EDTA) (Mickel et al., 1977; Hadler et al., 1983). The DNA fragments were then transferred to nitrocellulose filter (Southern, 1975) and hybridized with ${ }^{32}$ P-labeled human mtDNA. The mtDNAs used as probe were purified from human placentae or human cultured cells (Raji) and were nick translated (Rigby et al., 1977). After hybridization in X6 SSC/X1 Denhardt's solution/0.5\% SDS (Denhardt, 1966; Botchan et al., 1976), digested mtDNA patterns were analyzed using autoradiography.

\section{RESULTS AND DISCUSSION}

\section{Cleavage patterns}

AvaII: Six different cleavage patterns were observed with this enzyme in the Non-Ainu sample (Fig. 1), five of which (morph 1, 2, 3, 10 and 12) have been reported by Johnson et al. (1983) and Horai and Matsunaga (1986). Morph 1 is the most common type in most racial groups, while morph 2 and 3 also have been detected previously in Caucasians, African groups and the Japanese (Johnson et al., 1983; Horai and Matsunaga, 1986). Morph 2 and 3 correspond to morph 3 and 4, re- 


\section{Avall}

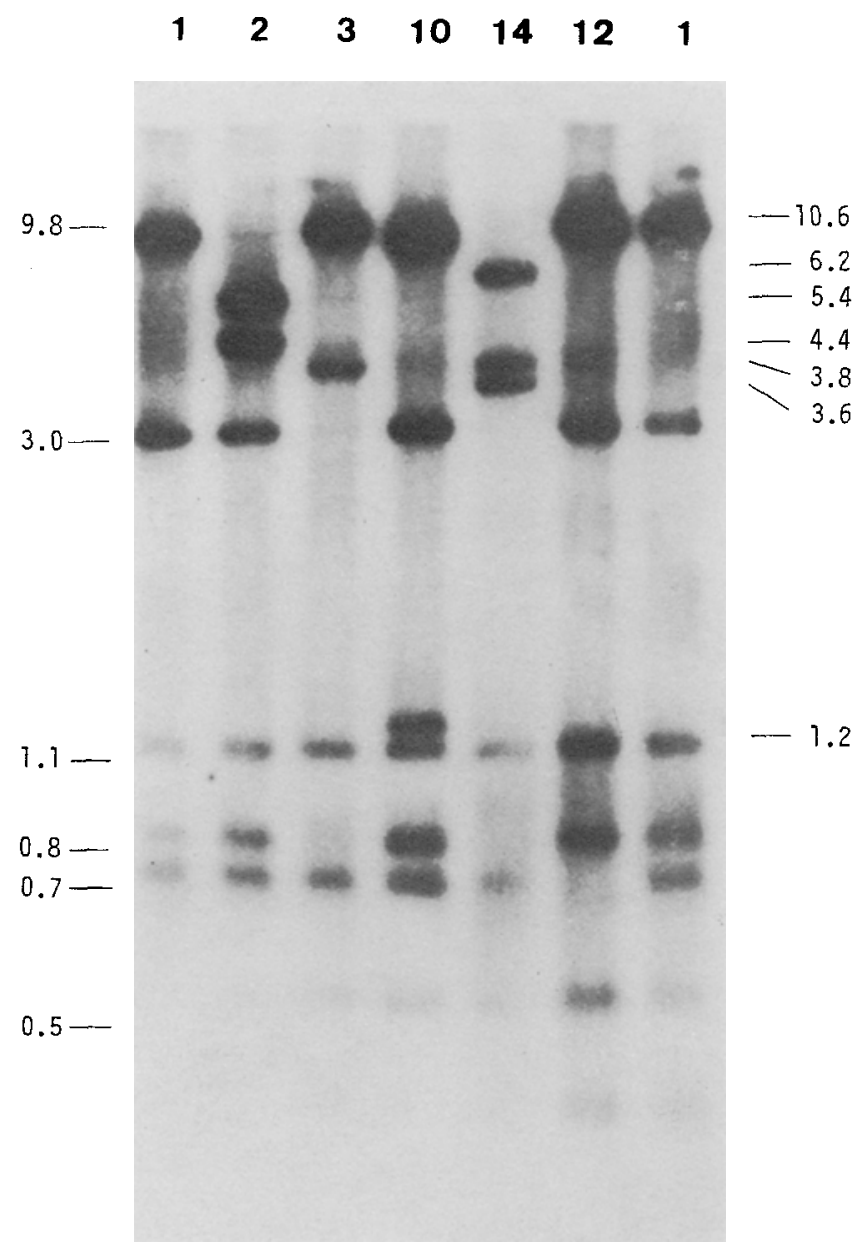

Fig. 1. Autoradiogram of Avall digestion patterns. Fragments were separated in $1.5 \%$ agarose gel. Morphs are denoted by numbers at top of lanes and fragment sizes are designated in kilo bases.

spectively, reported by Horai and Matsunaga (1986). Morph 10 has been reported only in Caucasians (Johnson et al., 1983), whereas morph 12 has been reported only in Japanese by Horai and Matsunaga (1986).

One other digestion pattern, which has not been reported previously, is named as morph 14. In morph $14,9.8 \mathrm{~kb}$ fragment is cleavaged into $6.2 \mathrm{~kb}$ and $3.6 \mathrm{~kb}$ fragments. In addition to this change, $3.0 \mathrm{~kb}$ and $0.8 \mathrm{~kb}$ fragments are fused to form $3.8 \mathrm{~kb}$ fragment. Using a double digestion with $A v a \mathrm{II}$ and EcoRI, the new site was found to be in the coding region of cytochrome $c$ oxidase subunit $\mathrm{I}$ (COI). The 


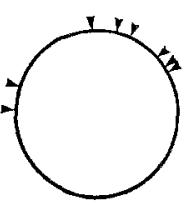

Avall-1

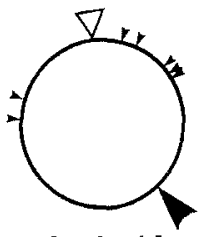

Avall-14

- site gained $D$ site lost

Fig. 2. Site changes in Avall morph 14. The locations of site loss and site gain are designated on the circular mtDNA map. The top of the circle corresponds to the site $0 \mathrm{bp}$ of the sequence of human mtDNA.

\section{Hinc II}

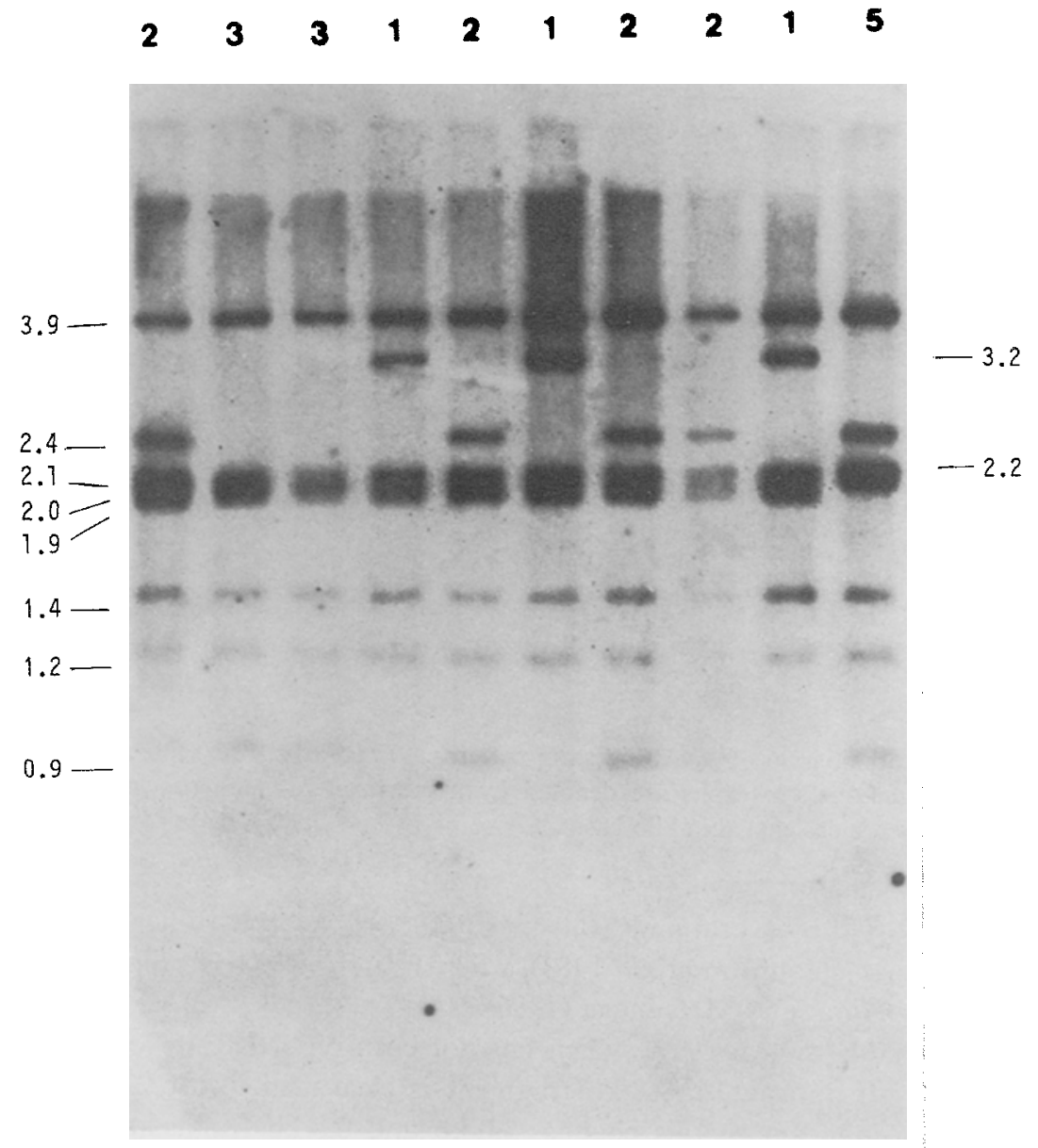

Fig. 3. Autoradiogram of HincII digestion patterns. Fragments were separated in $1.8 \%$ agarose gel. Morphs are denoted by numbers at top of lanes and fragment sizes are designated in kilo bases. 
base substitution may be $\mathrm{G}$ to $\mathrm{A}$, a transition, or $\mathrm{G}$ to $\mathrm{T}$, a transversion, at the site 6,384 base pair (bp) of the human mtDNA sequence (Anderson et al., 1981). This position corresponds to the first base of the codon for alanine. If the base change is $\mathrm{G}$ to $\mathrm{A}$, the amino acid encoded by this codon would change to threonine. If the base change is $G$ to $T$, alanine would be replaced by serine. A site loss occurs at the site $16,390 \mathrm{bp}$ in the non-coding region, and it seems to be the same change as found in morph 3. The changes giving birth to morph 14 are diagrammatically shown in Fig. 2.

HincII: Four different patterns were found in the Non-Ainu Japanese (Fig. 3). They were morph 1, 2, 3 and 5 reported by Blanc et al. (1983). In the Ainu, only three patterns, morph 1,2 and 3, were detected. The four morphs detected in the Japanese population in the present study, have been reported in Orientals (Blanc et al., 1983; Horai et al., 1984). Among them, morph 1 and morph 3 are common in Orientals but thus far have not been detected in Caucasians.

HpaI: Three distinct morphs, morph 1, 2 and 4, which have already been reported (Brown, 1980; Denaro et al., 1981), were detected when mtDNAs of the Ainu and the Non-Ainu Japanese were digested with Hpal (Fig. 4). Morph 1 has been detected in Africans (Bantu) and Orientals (Denaro et al., 1981). Morph 4 has

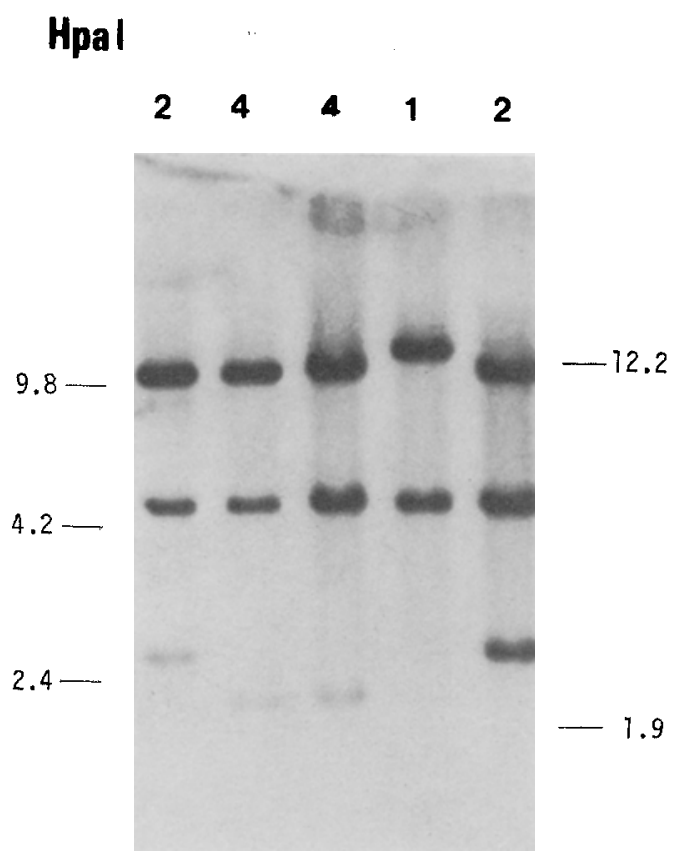

Fig. 4. Autoradiogram of HpaI digestion patterns. Fragments were separated in $1.0 \%$ agarose gel. Morphs are denoted by numbers at top of lanes and fragment sizes are designated in kilo bases. 
been detected only in Orientals (Denaro et al., 1981).

The variations in mtDNAs detected by $H p a \mathrm{I}$ were explained by HincII digestion patterns in the present study. HincII, which recognizes the sequence $G \mathrm{GT}\left({ }_{\mathrm{C}}^{\mathrm{T}}\right)$ $\left({ }_{\mathrm{G}}^{\mathrm{A}}\right) \mathrm{AC}$, also recognizes HpaI sites (GTTAAC). HpaI morph 1 and 4 completely correspond to HincII morph 1 and 3 respectively. Base changes, which cause HpaI site loss but not HincII site loss at the same site, or which generate new HpaI site at the HincII site, could not be detected.

PvuII: PvuII digestion patterns of human mtDNA usually show only one band, which is $16.5 \mathrm{~kb}$ fragment of total mtDNA. Horai et al. (1984) have reported one $P v u I I$ variant morph, morph 2 , in the Japanese. Another variant type was found in the present study and named as morph 3 . In morph 3 , two fragments $(10.1 \mathrm{~kb}$ and $6.4 \mathrm{~kb}$ ) were detected (Fig. 5). The double digestion with PvuII and BamHI and that with $P v u I I$ and $E c o$ RI showed that the extra site is in the coding region of URF-5, which is one of the components of respiratory-chain NADH dehydrogenase (Chomyn et al., 1985). The base change in this case may be A to $\mathrm{G}$, a transition, at the site $12,753 \mathrm{bp}$, which is the third base of the glutamine codon, and the base substitution may be a silent mutation. The location of the extra site in PvuII morph 3 is shown in Fig. 6.

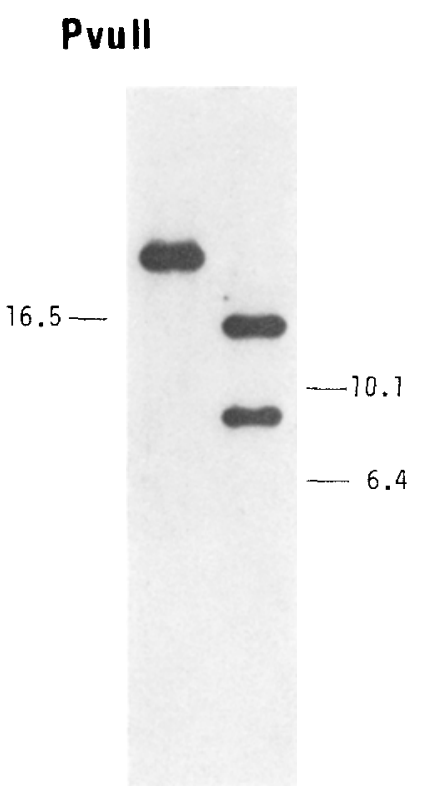

Fig. 5. Autoradiogram of $P v u I I$ digestion patterns. Fragments were separated in $0.7 \%$ agarose gel. Morphs are denoted by numbers and fragment sizes are designated in kilo bases. 


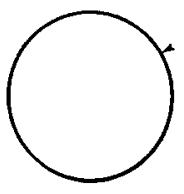

Pvull-1

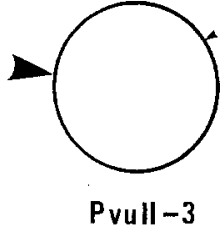

site gained

Fig. 6. Site gain in $P v u I I$ morph 3. The location is designated. The top of the circle corresponds to the site 0 bp of the human mtDNA sequence.

BamHI: No variant could be detected with BamHI and all the individuals showed morph 1 reported by Brown (1980) and Johnson et al. (1983). Other morphs, which have been observed only in Caucasians (Brown, 1980; Johnson et al., 1983), were found in neither the Ainu nor the Non-Ainu Japanese.

\section{Distribution of mtD NA morphs}

The Non-Ainu Japanese were highly polymorphic with AvaII and HincII digestion patterns, whereas the Ainu were less polymorphic with these enzymes (Table 1). However, the difference in the distribution of morphs between the two groups were not statistically significant for each enzyme (Table 2).

Horai and Matsunaga (1986) reported that five AvaII morphs were detected in the Japanese from central Japan. Four of them, morph 1, 2, 3 and 12, were found also in the present study. Among them, morph 12, which has been detected only in the Japanese may have potential value as a specific marker for Japanese. For the distribution of the Avall morphs, the frequency of morph 1 in the Non-Ainu in the present study is similar to that reported by Horai and Matsunaga (1986). Though the frequency of other morphs are different, there is no significant difference between the distribution of $A v a$ II morphs in the present study and that reported by Horai and Matsunaga $\left(\chi^{2}=8.8, \mathrm{df}=6,0.1<\mathrm{p}<0.2\right)$.

The distribution of HincII morphs in the Non-Ainu Japanese is also similar to the results of Horai et al. (1984) on the Japanese from central Japan, although morph 9,10 and 11 reported by them could not be detected in the present study. The frequency of morph 1 is slightly higher $(4.9 \%)$ than that in the study of Horai et al. $(3.3 \%)$. However, the distribution of HincII morphs in the present study is not significantly different from that reported by Horai et al. $\left(\chi^{2}=4.2, \mathrm{df}=6,0.5<\mathrm{p}<0.7\right)$.

mtDNA classification by the combination of enzymes

The mtDNAs of 122 Japanese examined in this study could be classified into eleven types by combining the results of three enzymes: $A v a I I$, HincII and PvuII (Table 3). Though the frequency of the most common type (type 1: AvaII morph 1-HincII morph 2-PvuII morph 1) is higher in the Ainu than in the Non-Ainu 
Table 1. Number of individuals and frequencies of all morphs listed by four restriction enzymes.

\begin{tabular}{|c|c|c|c|c|c|c|c|}
\hline & & \multicolumn{2}{|c|}{ Ainu Japanese } & \multicolumn{2}{|c|}{ Non-Ainu Japanese } & \multicolumn{2}{|c|}{ Total } \\
\hline \multirow{2}{*}{\multicolumn{2}{|c|}{$\begin{array}{l}\text { Sample size } \\
\text { Morph }\end{array}$}} & \multicolumn{2}{|c|}{48} & \multicolumn{2}{|c|}{74} & \multicolumn{2}{|c|}{122} \\
\hline & & No. & Freq. & No. & Freq. & No. & Freq. \\
\hline \multirow[t]{6}{*}{ Avall } & 1 & 48 & 100.0 & 66 & 89.2 & 114 & 93.4 \\
\hline & 2 & 0 & 0.0 & 1 & 1,4 & 1 & 0.8 \\
\hline & 3 & 0 & 0.0 & 2 & 2.7 & 2 & 1.6 \\
\hline & 10 & 0 & 0.0 & 3 & 4.1 & 3 & 2.5 \\
\hline & 12 & 0 & 0.0 & 1 & 1.4 & 1 & 0.8 \\
\hline & 14 & 0 & 0.0 & 1 & 1.4 & 1 & 0.8 \\
\hline \multirow[t]{4}{*}{ HincII } & 2 & 46 & 95.8 & 64 & 86.5 & 110 & 90.2 \\
\hline & 1 & 1 & 2.1 & 5 & 6.8 & 6 & 4.9 \\
\hline & 3 & 1 & 2.1 & 3 & 4. 1 & 4 & 3.3 \\
\hline & 5 & 0 & 0.0 & 2 & 2.7 & 2 & 1.6 \\
\hline \multirow[t]{3}{*}{$H p a \mathbf{I}$} & 2 & 46 & 95.8 & 66 & 89.2 & 112 & 91.8 \\
\hline & 1 & 1 & 2.1 & 5 & 6.8 & 6 & 4.9 \\
\hline & 4 & 1 & 2.1 & 3 & 4.1 & 4 & 3.3 \\
\hline \multirow[t]{2}{*}{ РvиЈ } & 1 & 46 & 100.0 & 73 & 98.6 & 121 & 99.2 \\
\hline & 3 & 0 & 0.0 & 1 & 1.4 & 1 & 0.8 \\
\hline
\end{tabular}

Table 2. $\chi^{2}$ value to test difference between distribution of the Ainu and that of the Non-Ainu.

\begin{tabular}{llll}
\hline Digestion & $\chi^{2}$ & df & $\mathrm{p}$ \\
\hline AvaII & 5.7 & 5 & $0.3<\mathrm{p}<0.5$ \\
HincII & 3.3 & 3 & $0.3<\mathrm{p}<0.5$ \\
HpaI & 1.8 & 2 & $0.3<\mathrm{p}<0.5$ \\
PvuII & 0.7 & 1 & $0.3<\mathrm{p}<0.5$ \\
\hline
\end{tabular}

sample, and there are fewer variant types in the Ainu sample, the distribution of the two groups are not significantly different $\left(\chi^{2}=9.3, \mathrm{df}=10,0.3<\mathrm{p}<0.5\right)$.

Frequencies of other types except for type 1 are low both in the Ainu and in the Non-Ainu Japanese. Since $P v u I I$ morph 3 was found only in one individual, the variability of distribution is mainly attributed to the digestion patterns of the following two enzymes: AvaII and HincII.

Relation between the Ainu and the Non-Ainu Japanese

In the Ainu, 46 individuals $(95.8 \%$ ) had mtDNA type 1 , while, two individuals 
Table 3. Number of individuals and frequencies of mtDNA types classified by all morphs of three enzymes. Enzyme morphs are listed in parentheses in the order: AvaII, HincII, PvuII.

\begin{tabular}{crrrrrr}
\hline & \multicolumn{2}{c}{ Ainu Japanese } & Non-Ainu Japanese & \multicolumn{2}{c}{ Total } \\
\hline Sample size & \multicolumn{2}{c}{48} & \multicolumn{2}{c}{74} & \multicolumn{2}{c}{122} \\
mtDNA type & No. & Freq. & No. & Freq. & No. & Freq. \\
\hline $1(1-2-1)$ & 46 & 95.8 & 57 & 77.7 & 103 & 84.4 \\
$2(1-1-1)$ & 1 & 2.1 & 4 & 5.4 & 5 & 4.1 \\
$3(10-2-1)$ & 0 & 0.0 & 3 & 4.1 & 3 & 2.5 \\
$4(1-3-1)$ & 1 & 2.1 & 2 & 2.7 & 3 & 2.5 \\
$5(1-5-1)$ & 0 & 0.0 & 2 & 2.7 & 2 & 1.6 \\
$6(2-2-1)$ & 0 & 0.0 & 1 & 1.4 & 1 & 0.8 \\
$7(3-2-1)$ & 0 & 0.0 & 1 & 1.4 & 1 & 0.8 \\
$8(3-3-1)$ & 0 & 0.0 & 1 & 1.4 & 1 & 0.8 \\
$9(12-1-1)$ & 0 & 0.0 & 1 & 1.4 & I & 0.8 \\
$10(14-2-1)$ & 0 & 0.0 & 1 & 1.4 & 1 & 0.8 \\
$11(1-2-3)$ & 0 & 0.0 & 1 & 1.4 & 1 & 0.8 \\
\hline
\end{tabular}

$(4.2 \%)$ showed other types (type 2 and type 4) differing from type 1 as to HincII morph. In the Non-Ainu, the mtDNAs of 74 individuals were classified into eleven types and the frequency of type 1 was $78.4 \%$.

Though the mtDNAs of the Ainu were less polymorphic than those of the NonAinu, the present result does not show great divergence between the two groups. The low level of variation of the Ainu sample may be ascribed to the small sample size and the random genetic drift. The three mtDNA types found in the Ainu were also found in the Non-Ainu and no significant difference was detected between the two groups. These results are compatible with those of the recent genetic studies using blood protein and antigen markers suggesting that the Ainu have closer genetic relation to Mongoloids than to Caucasoids or other racial groups (Misawa and Hayashida, 1968; Mittal et al., 1972; Omoto, 1972).

The present-day Ainu population show considerable degree of admixture with Non-Ainu Japanese immigrants and it is known that the intermarriages predominantly took place between Ainu women and Non-Ainu men (Omoto, 1973). Therefore, mtDNA with its maternal inheritance may have advantages over nuclear genes as the genetic marker for studying the origins of the Ainu. Although more material is clearly needed for a final conclusion, the result of this study may be taken as a clue to substantiate the views that the genetic affinities of the Ainu to Mongoloids are the true ones and are not due to gene flow in the recent times (Omoto, 1975).

Acknowledgments The authors are deeply indebted to Professor Saburo Watanabe and Dr. Hiroo Kimura for arrangements to obtain blood samples. This study was supported by the Grantin-Aid for Scientific Research (No. 59106002) from the Ministry of Education, Science and Culture of Japan. 


\section{REFERENCES}

Anderson, S., Bankier, A.T., Barrell, B.G., de Bruijn, M.H.L., Coulson, A.R., Drouin, J., Eperon, I.C., Nierlich, D.P., Roe, B.A., Sanger, F., Schreier, P.H., Smith, A.J.H., Staden, R., and Young, I.G. 1981. Sequence and organization of the human mitochondrial genome. Nature 290: $457-465$.

Blanc, H., Chen, K.H., D'Amore, M.A., and Wallace, D.C. 1983. Amino acid change associated with the major polymorphic HincII site of Oriental and Caucasian mitochondrial DNAs. Am. I. Hum. Genet. 35: 167-176.

Botchan, M., Topp, W., and Sambrook, J. 1976. The arrangement of simian virus 40 sequences in the DNA of transformed cells. Cell 9:269-287.

Brown, W.M. 1980. Polymorphism in mitochondrial DNA of humans as revealed by restriction endonuclease analysis. Proc. Natl. Acad. Sci. U.S.A. 77: 3605-3609.

Cann, R.L. and Wilson, A.C. 1983. Length mutations in human mitochondrial DNA. Genetics 104: 699-711.

Cann, R.L., Brown, W.M., and Wilson, A.C. 1.984. Polymorphic sites and the mechanism of evolution in human mitochondrial DNA. Genetics 106: 479-499.

Case, J.T. and Wallace, D.C. 1981. Maternal inheritance of mitochondrial DNA polymorphisms in human cultured fibroblasts. Somatic Cell Genet. $7:$ 103-108.

Chomyn, A., Mariottini, P., Cleeter, M.W.J., Ragan, C.I., Matsuno-Yagi, A., Hatefi, Y., Doolittle, R.F., and Attardi, G. 1985. Six unidentified reading frames of human mitochondrial DNA encode components of the respiratory-chain NADH dehydrogenase. Nature 314: 592-597.

Denaro, M., Blanc, H., Johnson, M.J., Chen, K.H., Wilmsen, E., Cavalli-Sforza, L.L., and Wallace, D.C. 1981. Ethnic variation in $H p a I$ endonuclease cleavage patterns of human mitochondrial DNA. Proc. Natl. Acad. Sci. U.S.A. 78: 5768-5772.

Denhardt, D.T. 1966. A membrane-filter technique for the detection of complementary DNA. Biochem. Biophys. Res. Chmmun. 23: 641-646.

Giles, R.E., Blanc, H., Cann, H.M., and Wallace, D.C. 1980. Maternal inheritance of human mitochondrial DNA. Proc. Natl. Acad. Sci. U.S.A. 77:6715-6719.

Hadler, H.I., Dimitrijevic, B., and Mahalingam, R. 1983. Mitochondrial DNA and nuclear DNA from rat liver have a common sequence. Proc. Natl. Acad. Sci. U.S.A. 80: 6495-6499.

Horai, S., Gojobori, T., and Matsunaga, E. 1984. Mitochondrial DNA polymorphism in Japanese. I. Analysis with restriction enzymes of six base pair recognition. Hum. Genet. 68: 324-332.

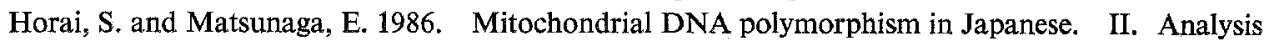
with restriction enzymes of four or five base pair recognition. Hum. Genet. 72: 105-117.

Hutchison, C.A., III, Newbold, J.E., Potter, S.S., and Edgel, M.H. 1974. Maternal inheritance of mammalian mitochondrial DNA. Nature 251: 536-538.

Johnson, M.J., Wallace, D.C., Ferris, S.D., Rattazzi, M.C., and Cavalli-Sforza, L.L. 1983. Radiation of human mitochondria DNA types analyzed by restriction endonuclease cleavage patterns. J. Mol. Evol. 19: 255-271.

Kan, Y.W., Dozy, A.M., Trecartin, R., and Todd, D. 1977. Identification of a nondeletion defect in $\alpha$-thalassemia. N. Engl. J. Med. 297: 1081-1084.

Mickel, S., Arena, V., Jr., and Bauer, W. 1977. Physical properties and gel electrophoresis behavior of R-12 derived plasmid DNAs. Nucl. Acids Res. 4: 1465-1482.

Misawa, S. and Hayashida, Y. 1968. On the blood groups among the Ainu in Shizunai, Hokkaido. Proc. Jpn. Acad. 44: 83-88.

Mittal, K.K., Hasegawa, T., Ting, A., Mickey, M.R., and Terasaki, P.I. 1972. Genetic variation in the HL-A system between Ainus, Japanese, and Caucasians. In Histocompatibility Testing 1972, Munksgaard, Copenhagen, pp. 187-195. 
Omoto, K. 1972. Polymorphism and genetic affinities of the Ainu of Hokkaido. Hum. Biol. Oceania 1: 278-288.

Omoto, K. 1973. The Ainu: A racial isolate? Israel J. Med. Sci. 9: 1285-1290.

Omoto, K. 1975. Genetic composition of the Ainu: Genetic affinities of the Ainu as assessed from the data on polymorphic traits. In JIBP Synthesis 2, Anthropological and Genetic Studies on Japanese, Watanabe, S., Kondo, S, and Matsunaga, E., eds., Univ. Tokyo Press, Tokyo, pp. 296-303.

Rigby, P.W.J., Dieckmann, M., Rhodes, C., and Berg, P. 1977. Labeling deoxyribonucleic acid to high specific activity in vitro by nick translation with DNA polymerase I. J. Mol. Biol. 113: 237-251.

Southern, E.M. 1975. Detection of specific sequences among DNA fragments separated by gel electrophoresis. J. Mol. Biol. 98: 503-517.

Wallace, D.C., Garrison, K., and Knowler, W.C. 1985. Dramatic founder effects in Amerindian mitochondrial DNAs. Am. J. Phys. Anthropol. 68: 149-155. 